\title{
Dissociation of methionine synthetase ( $E C$ 2.1.1.13) activity and impairment of DNA synthesis in fruit bats (Rousettus aegyptiacus) with nitrous oxide-induced vitamin $B_{12}$ deficiency
}

\author{
BY SUSAN V. VAN TONDER, ANGELA RUCK, J. VAN DER \\ WESTHUYZEN, F. FERNANDES-COSTA* AND J. METZ \\ Department of Haematology, School of Pathology of the South African Institute for \\ Medical Research, PO Box 1038, Johannesburg 2000, South Africa and the University of \\ the Witwatersrand, Johannesburg, South Africa
}

(Received 2 July 1985 - Accepted 9 August 1985)

\begin{abstract}
1. The effect of methylcobalamin inactivation by the anaesthetic gas nitrous oxide on the activity of the cobalamin-dependent methionine synthetase (5-methyltetrahydrofolate homocysteine methyltransferase; EC 2.1.1.13) reaction, and on DNA synthesis, in the fruit bat Rousettus aegyptiacus, was examined.

2. Methionine synthetase activity in the liver of bats exposed to $\mathrm{N}_{2} \mathrm{O}-$ oxygen $(50: 50, \mathrm{v} / \mathrm{v})$ for $90 \mathrm{~min} / \mathrm{d}$ averaged $32 \%$ of that of controls after $4 \mathrm{~d}$ of exposure and only $5 \%$ after 12-14 weeks of exposure.

3. DNA synthesis in the bone marrow, as reflected by the deoxyuridine suppression test, was unaffected by $4 \mathrm{~d}$ of exposure to $\mathrm{N}_{2} \mathrm{O}$ and only minimally affected after 5-10 weeks of exposure.

4. These results suggest that DNA synthesis in the fruit bat is unusually resistant to inhibition of methionine synthetase and imply the existence of a non-methylated circulating folate pool in this species.
\end{abstract}

Nitrous oxide oxidizes active reduced cob(I)alamin to inactive cob(III)alamin (Banks et al. 1968). Exposure to the gas results in inhibition of one of the mammalian vitamin $B_{12}$-dependent enzymes, methionine synthetase (5-methyltetrahydrofolate homocysteine methyltransferase; EC 2.1.1.13) (Deacon et al. 1978), which requires methylcobalmin as cofactor. In humans (Amess et al. 1978), monkeys (Dinn et al. 1978) and rats (Deacon et $a l .1980 a, b)$ the inhibition of methionine synthetase induced by short-term exposure to $\mathrm{N}_{2} \mathrm{O}$ is accompanied by abnormal de novo synthesis of DNA, as demonstrated by the deoxyuridine (dU) suppression test (Killman, 1964; Metz et al. 1968). It is probable that inhibition of methionine synthetase is related directly to abnormal DNA synthesis (Herbert \& Zalusky, 1962; Noronha \& Silverman, 1962; reviewed by Das \& Herbert, 1976). Prolonged exposure to $\mathrm{N}_{2} \mathrm{O}$ also depletes the animal's vitamin $\mathrm{B}_{12}$ stores (Kondo et al. 1981; van der Westhuyzen et al. 1982).

In the fruit bat (Rousettus aegyptiacus) deprived of dietary vitamin $\mathrm{B}_{12}$, severe deficiency of the vitamin ensues (Green et al. 1975) but, in contrast to man and other animals, DNA synthesis remains unaffected as shown by a normal dU suppression test (Miller et al. 1980). This unexpected observation led to the present study of the dU suppression test in fruit bats exposed to $\mathrm{N}_{2} \mathrm{O}$, for the degree of inhibition by $\mathrm{N}_{2} \mathrm{O}$ of the methylcobalamin-dependent methionine synthetase reaction may be greater than that associated with dietary vitamin $B_{12}$ deprivation since, in the latter situation, some metabolically-active coenzyme is likely always to be present.

The results indicate that short-term exposure to $\mathrm{N}_{2} \mathrm{O}$ caused severe inhibition of methionine synthetase activity without affecting DNA synthesis. With long-term exposure, methionine synthetase activity fell to almost undetectable levels, yet the effect on DNA synthesis was minimal. 


\section{MATERIALS AND METHODS \\ Experimental animals}

Fruit bats (Rousettus aegyptiacus) were captured in the wild and maintained on a pest-free, all-fruit diet (Green et al. 1975; van Tonder et al. 1975), supplemented with an oral vitamin $B_{12}$-free multivitamin preparation ('Abidec'; Parke Davis) to prevent the development of deficiency of other vitamins (van der Westhuyzen et al. 1982).

\section{Experimental procedure}

Bats were exposed in a chamber to an atmosphere of $\mathrm{N}_{2} \mathrm{O}$-oxygen $(50: 50, \mathrm{v} / \mathrm{v})$ for $90 \mathrm{~min}$ daily. During exposure, levels of carbon dioxide and water vapour were controlled. Both short-term (4 d) and long-term (5-14 weeks) exposures were studied. At the end of the experiment, bats were killed by exsanguination via cardiac puncture and the liver removed immediately after death and stored on ice. Bone marrow was removed from the long bones and placed in ice-cold Hanks balanced salt solution (without $\mathrm{pH}$ indicator). Paired control and $\mathrm{N}_{2} \mathrm{O}$-exposed bats were killed at the same time. The dU suppression test on marrow, and methionine synthetase assay on liver, were carried out immediately after the death of the animals.

\section{Methionine synthetase assay}

Methionine synthetase activity in the liver was assayed by the method of Taylor \& Wiessbach (1971) in which the rate of formation of $\left[{ }^{14} \mathrm{C}\right]$ methionine from homocysteine in the presence of $\left[{ }^{14} \mathrm{C}\right]$ methyltetrahydrofolate and S-adenosylmethionine is measured. All assays were performed in triplicate. The $\left[{ }^{14} \mathrm{C}\right]$ methyltetrahydrofolate was obtained from Amersham International (Amersham, Bucks, UK), L-homocysteine from Sigma Chemical Co. (Poole, Dorset, UK) and S-adenosylmethionine from Boehringer Mannheim.

\section{$d U$ suppression test}

The dU suppression test was performed on bone marrow cells as described previously (Metz et al. 1968; Miller et al. 1980). dU, which is incubated with the cell suspension in the first part of the test, is normally converted into thymidine in a folate-requiring step and incorporated into DNA. Vitamin $\mathbf{B}_{12}$ coenzyme activity is assayed indirectly, since in the methionine synthetase reaction it is required for the conversion of the circulating form of folate (methyltetrahydrofolate) into the form involved in thymidine synthesis $(5,10-$ methylenetetrahydrofolate). In the second part of the test, preformed $\left[{ }^{3} \mathrm{H}\right]$ thymidine is added to the cell suspension so that any requirements for DNA synthesis not met by synthesis from $\mathrm{dU}$ is met by incorporation of $\left[{ }^{3} \mathrm{H}\right]$ thymidine. The result is expressed as:

$$
\frac{\left[{ }^{3} \mathrm{H}\right] \text { thymidine uptake after } \mathrm{dU}}{\left[{ }^{3} \mathrm{H}\right] \text { thymidine uptake alone }} \times 100 \text {. }
$$

Normal human marrow meets more than $90 \%$ of its thymidine requirements from dU so that less than $10 \%\left[{ }^{3} \mathrm{H}\right]$ thymidine is utilized. Abnormal values $(>10 \%)$ are obtained in cobalamin deficiency (Metz et al. 1968).

\section{Statistical analyses}

Statistical evaluation was carried out using Student's $t$-test (two-tailed). The level of significance was chosen as $P<0.05$. Results are expressed as means with their standard errors. 
Table 1. Methionine synthetase (5-methyltetrahydrofolate homocysteine methyltransferase; EC 2.1.1.13) activity in the liver of control and nitrous oxide-exposed fruit bats (Rousettus aegyptiacus)

(Mean values with their standard errors)

\begin{tabular}{|c|c|c|c|c|}
\hline \multirow[b]{3}{*}{ Group } & \multirow[b]{3}{*}{$n$} & \multicolumn{3}{|c|}{ Enzyme activity } \\
\hline & & \multicolumn{2}{|c|}{$\mathrm{nmol} / \mathrm{h}$ per $\mathrm{mg}$ protein } & \multirow{2}{*}{$\begin{array}{l}\text { Percentage } \\
\text { of control }\end{array}$} \\
\hline & & Mean & $\mathbf{S E}$ & \\
\hline Control & 6 & $3 \cdot 9$ & 0.8 & 100 \\
\hline $\begin{array}{l}\mathrm{N}_{2} \mathrm{O} \\
\quad 4 \mathrm{~d} \\
\quad 12-14 \text { weeks }\end{array}$ & $\begin{array}{l}7 \\
3\end{array}$ & $\begin{array}{l}1 \cdot 3^{*} \\
0 \cdot 4^{*}\end{array}$ & $\begin{array}{l}0.5 \\
0 \cdot 1\end{array}$ & $\begin{array}{r}32 \\
5\end{array}$ \\
\hline
\end{tabular}

Mean value was significantly different from control value: $* P<0.02$.

Table 2. Results of the deoxyuridine (dU) suppression test with marrow cells of normal and nitrous oxide-exposed fruit bats (Rousettus aegyptiacus)

(Mean values with their standard errors)

\begin{tabular}{|c|c|c|c|c|c|c|c|c|c|c|}
\hline \multirow[b]{3}{*}{ Group } & \multirow[b]{3}{*}{$n$} & \multicolumn{9}{|c|}{$\frac{\text { Counts with } \mathrm{dU}+\left[{ }^{3} \mathrm{H}\right] \text { thymidine }}{\text { counts with }\left[{ }^{3} \mathrm{H}\right] \text { thymidine alone }} \times 100$} \\
\hline & & \multicolumn{3}{|c|}{ dU alone } & \multicolumn{3}{|c|}{$d U+P G A$} & \multicolumn{3}{|c|}{$\mathrm{dU}+$ cyanocobalamin } \\
\hline & & Mean & $\mathbf{S E}$ & Range & Mean & $\mathbf{S E}$ & Range & Mean & $\mathbf{S E}$ & Range \\
\hline Control & 6 & $1 \cdot 5$ & 0.3 & $0.9-3.1$ & $1 \cdot 3$ & 0.3 & $0.8-2.9$ & $1 \cdot 3$ & $0 \cdot 2$ & $0 \cdot 7-2 \cdot 5$ \\
\hline $\begin{array}{l}\mathrm{N}_{2} \mathrm{O} \\
\quad 4 \mathrm{~d} \\
5-10 \text { weeks }\end{array}$ & $\begin{array}{r}5 \\
10\end{array}$ & $\begin{array}{l}1 \cdot 4 \\
4 \cdot 4^{*}\end{array}$ & $\begin{array}{l}0.3 \\
1 \cdot 0\end{array}$ & $\begin{array}{l}0.7-2 \cdot 0 \\
0.9-10 \cdot 5\end{array}$ & $\begin{array}{l}1 \cdot 2 \\
2 \cdot 7\end{array}$ & $\begin{array}{l}0.4 \\
0.6\end{array}$ & $\begin{array}{r}0.6-2 \cdot 0 \\
0.8-7 \cdot 0\end{array}$ & $\begin{array}{l}1.4 \\
3.4\end{array}$ & $\begin{array}{l}0.4 \\
0.7\end{array}$ & $\begin{array}{l}0.5-2.4 \\
0.8-8.4\end{array}$ \\
\hline
\end{tabular}

PGA, pteroylglutamic acid.

Mean value was significantly different from control value: $\bullet P<0.05$.

\section{RESULTS}

Methionine synthetase activity (Table 1)

Methionine synthetase activity was decreased in the liver of all bats exposed to $\mathrm{N}_{2} \mathrm{O}$ compared with that of control animals. In short-term exposure, enzyme activity averaged $32 \%$ of that of control animals, and with prolonged exposure, the activity was almost undetectable $( \pm 5 \%)$. The difference in degree of reduction in both short-term and long-term exposures, as compared with control animals, was statistically significant $(P<0.02)$.

\section{dU suppression test (Table 2)}

The mean degree of suppression by $\mathrm{dU}$ in the bone marrow of bats after $4 \mathrm{~d}$ of exposure to $\mathrm{N}_{2} \mathrm{O}$ (mean 1.4 (SE 0.3 ) \%) did not differ significantly from that in control animals (mean 1.5 (SE 0.3)\%). However, after long-term exposure to $\mathrm{N}_{2} \mathrm{O}$ (mean 6.6 (SE 0.4)weeks) the degree of suppression by dU (mean $4.4(\mathrm{SE} 1.0) \%$ ) was significantly less than that of control 
animals $(P<0.05)$ and of animals following short-term exposure to $\mathrm{N}_{2} \mathrm{O}$, although in the latter case the difference just failed to be statistically significant. The addition of either folate in the form of pteroylglutamic acid (PGA) or cyanocobalamin to the marrow cultures of animals after long-term exposure to $\mathrm{N}_{2} \mathrm{O}$ produced a greater degree of $\mathrm{dU}$ suppression, so that the differences in the results of the dU suppression test between these and control animals was no longer statistically significant (Table 2). The corrective effect of PGA was greater than that of cyanocobalamin.

\section{DISCUSSION}

The effect of methionine synthetase activity in the liver or brain, or both, of rats exposed to $\mathrm{N}_{2} \mathrm{O}$ has been reported by Deacon et al. $(1978,1979,1980 a, b)$ and Kondo et al. (1981). Deacon et al. $(1978,1979,1980 a, b)$ found the levels of enzyme activity in the liver of control rats to range from 1.4 to $3.4 \mathrm{nmol} / \mathrm{h}$ per $\mathrm{mg}$ protein; the synthetase activity after $30 \mathrm{~min}$ exposure to $\mathrm{N}_{2} \mathrm{O}-\mathrm{O}_{2}(50: 50, \mathrm{v} / \mathrm{v})$ declined to $0.35-0.7 \mathrm{nmol} / \mathrm{h}$ per mg protein $(30 \%$ of control) and, after $6 \mathrm{~h}$ of exposure, was virtually absent $(0.03-0.04 \mathrm{nmol} / \mathrm{h}$ per $\mathrm{mg}$ protein; $6 \%$ of control). The dU suppression test became abnormal shortly after the inactivation of the enzyme. Brain methionine synthetase was depressed in a similar manner by exposure to $\mathrm{N}_{2} \mathrm{O}$. Kondo et al. (1981) also showed a fall in activity in the liver of rats exposed to $\mathrm{N}_{2} \mathrm{O}-\mathrm{O}_{2}(50: 50, v / v)$, but the degree of inhibition of the enzyme was less than that reported by Deacon et al. $(1978,1979,1980 a, b)$. Thus $15 \mathrm{~min}$ of exposure caused the level of methionine synthetase activity to decrease to $45 \%$ of control values, and activity fell to $30 \%$ after $1 \mathrm{~h}$ and remained at this level for exposure periods up to $2 \mathrm{~d}$. With longer exposure, methionine synthetase activity decreased further to 18 and $12 \%$ of control values after 16 and $33 \mathrm{~d}$ respectively.

The results of the present study show that in the fruit bat too, exposure to $\mathrm{N}_{2} \mathrm{O}-\mathrm{O}_{2}(50: 50$, $\mathrm{v} / \mathrm{v})$ results in inhibition of the methionine synthetase enzyme. Deacon et al. $(1978,1979$, $1980 a, b)$ and Kondo et al. (1981) exposed rats continuously to $\mathrm{N}_{2} \mathrm{O}$. This is not possible in the bat, a free-flying animal, and in the present experiments exposure was intermittent $(90 \mathrm{~min} / \mathrm{d})$. However, it is most unlikely that the effects of intermittent exposure would be different from that of continuous exposure, for the rate of recovery of methionine synthetase following exposure to $\mathrm{N}_{2} \mathrm{O}$ is extremely slow (Deacon et al. 1979; Kondo et al. 1981). The degree of inhibition of the enzyme in relation to the length of exposure was less in the bat than that reported by Deacon et al. (1979) in the rat, and more like that reported by Kondo et al. (1981) in the rat. The values reported by Deacon et al. (1979) and Kondo et al. (1981) for the rat differ in the degree of methionine synthetase inhibition produced by $\mathrm{N}_{2} \mathrm{O}-\mathrm{O}_{2}$ (50:50, v/v) making comparison with the values for the bat difficult. However, the important finding was that with adequate exposure (12-14 weeks), methionine synthetase activity virtually disappeared from bat liver.

Deacon et al. $(1980 \mathrm{~b})$ reported that in five marrows from control rats the dU suppression test mean was $6.6 \%$. After $60 \mathrm{~min}$ of exposure to $\mathrm{N}_{2} \mathrm{O}$ it became abnormal, and increasingly abnormal till $6 \mathrm{~h}$. There was usually a small improvement in the test of the order of $2-3 \%$ when $10 \mu \mathrm{g}$ hydroxycobalamin was added, and a somewhat greater fall when folate in the form of folinic acid $(30 \mu \mathrm{g})$ was added in vitro. In another paper, Deacon et al. $(1980 \mathrm{a})$ reported on studies of rats exposed to $\mathrm{N}_{2} \mathrm{O}-\mathrm{O}_{2}(50: 50, v / v)$ for $3 \mathrm{~h}$. In forty control rats, the mean dU suppression was $7 \cdot 3 \%$. After $3 \mathrm{~h}$ of exposure to $\mathrm{N}_{2} \mathrm{O}$ the dU suppression test was abnormal, the mean being $15 \cdot 7 \%$. There was no significant improvement in $\mathrm{dU}$ utilization on addition of $10 \mu \mathrm{g}$ PGA; an improved dU utilization occurred with the addition of formylfolate.

The results in man differ from those reported in rats by Deacon et al. $(1980 a, b)$. In 
patients receiving $\mathrm{N}_{2} \mathrm{O}-\mathrm{O}_{2}(50: 50, \mathrm{v} / \mathrm{v})$ for $24 \mathrm{~h}$, the mean dU suppression was $19.9 \%$ (controls mean $4.0 \%$ ) (Amess et al. 1978). The addition of $4 \mu \mathrm{g}$ cyanocobalamin or $40 \mu \mathrm{g}$ PGA produced significant correction in the $\mathrm{dU}$ suppression test, to 11.2 and $9.0 \%$ respectively. These results were confirmed in a further study of forty-two patients receiving $\mathrm{N}_{2} \mathrm{O}-\mathrm{O}_{2}(50: 50, \mathrm{v} / \mathrm{v})$ (Amos et al. 1982). The dU suppression was abnormal in almost all patients, and significant partial correction occurred on addition of cyanocobalamin or PGA.

The effect of $\mathrm{N}_{2} \mathrm{O}$ exposure on the dU suppression test in the bat, as shown in the present study, differed from those reported for man and the rat. Thus exposure of the bat to $\mathrm{N}_{2} \mathrm{O}$ for $4 \mathrm{~d}$ failed to affect the dU suppression test. After 5-10 weeks of exposure to the gas, the $\mathrm{dU}$ suppression test in the bat was only mildly affected, in spite of the fact that methionine synthetase activity in the liver was virtually absent.

Methionine synthetase is the enzyme responsible for demethylating methyltetrahydrofolate (Poston \& Stadtman, 1975), the major transport form of folate in man (Herbert et al. 1962) and probably in most other mammals (Scott \& Weir, 1976). Without the initial demethylation step, folate is not available for intracellular metabolism (Scott \& Weir, 1976) and normal dU utilization will not occur (reviewed by Das \& Herbert, 1976) since its conversion to 5,10-methylenetetrahydrofolate is impaired.

Thus, depression of methionine synthetase appears to be the basis of the abnormal dU suppression test in vitamin $B_{12}$ deficiency in humans (Killman, 1964; Metz et al. 1968), and following exposure to $\mathrm{N}_{2} \mathrm{O}$ in humans (Amess et al. 1978), rats (Deacon et al. 1980a) and monkeys (Dinn et al. 1978).

DNA synthesis in the fruit bat appears to be unusually resistant to inhibition of methionine synthetase since neither profound dietary vitamin $\mathrm{B}_{12}$ deficiency (Miller et al. 1980) nor short-term $\mathrm{N}_{2} \mathrm{O}$ exposure affects the dU suppression test. Only prolonged $\mathrm{N}_{2} \mathrm{O}$ exposure results in abnormal dU suppression and even then the effect is slight. This is contrary to the findings in other mammalian species in which short-term exposure to $\mathrm{N}_{2} \mathrm{O}$ has an immediate effect on the dU suppression test. As in other animals, dU suppression in the fruit bat is folate-dependent, for the addition of methotrexate, a potent inhibitor of the key enzyme dihydrofolate reductase $(E C$ 1.5.1.3), results in a markedly abnormal dU suppression test (Miller et al. 1980). Thus the $\mathrm{N}_{2} \mathrm{O}$-treated bat has adequate metabolically active folate despite inhibition of the enzyme which in other species plays a key role in the provision of this form of folate.

The possible reason for the resistance of the fruit bat to the effects of dietary vitamin $B_{12}$ deficiency or $\mathrm{N}_{2} \mathrm{O}$ exposure on DNA synthesis may be related to the finding that the fruit bat has a non-methylated pool of circulating folate which is separate from the methyltetrahydrofolate pool (Perry et al. 1979). Folate from the non-methylated pool would be able to enter the metabolically active pool directly, by-passing the methionine synthetasedependent step. Such a mechanism may have evolved in the fruit bat since, in the wild, it subsists on an exclusive fruit diet (fruit contains no vitamin $B_{12}$ ), and thus its vitamin $B_{12}$ nutrition might be expected to be marginal. A protective pathway to serve as an escape from the effects of vitamin $B_{12}$ deficiency would obviously be advantageous.

Supported in part by grants from the Medical Research Council and Atomic Energy Board, South Africa.

Amess, J. A. L., Burman, J. F., Rees, G. M., Nancekievill, D. J. \& Mollin, D. L. (1978). Lancet ii, 339-342. Amos, R. J., Amess, J. A. L., Hinds, C. J. \& Mollin, D. L. (1982). Lancet ii, 835-839.

Banks, R. G. S., Henderson, R. J. \& Pratt, J. M. (1968). Journal of the Chemistry Society A, 2886-2888.

Das, K. C. \& Herbert, V. (1976). Seminars in Haematology 5, 697-726. 
Deacon, R., Chanarin, I., Perry, J. \& Lumb, M. (1980a). Biochemical and Biophysical Research Communications 93, 516-520.

Deacon, R., Lumb, M., Muir, M., Perry, J., Chanarin, I., Minty, B., Halsey, M. J. \& Nunn, J. (1979). In Vitamin $B_{12}$, pp. 1055-1060 [B. Zagalak and W. Friedrich, editors]. Berlin: W. de Gruyter.

Deacon, R., Lumb, M., Perry, J., Chanarin, I., Minty, B., Halsey, M. J. \& Nunn, J. F. (1978). Lancet ii, $1023-1024$.

Deacon, R., Lumb, M., Perry, J., Chanarin, I., Minty, B., Halsey, M. \& Nunn, J. (1980 b). Journal of Biochemistry 104, 419-422.

Dinn, J. J., McCann, S., Wilson, P., Reed, B., Weir, D. and Scott, J. (1978). Lancet ii, 1154.

Green, R. S., van Tonder, S. V., Oettle, G. J., Cole, G. \& Metz, J. (1975). Nature 254, 148-150.

Herbert, V., Larrabee, A. R. \& Buchanan, J. M. (1962). Journal of Clinical Investigation 41, 1134-1138.

Herbert, V. \& Zalusky, R. (1962). Journal of Clinical Investigation 41, $1263-1276$.

Killman, S. A. (1964). Acta Medica Scandinavica 175, 483-497.

Kondo, H., Osborne, M. L., Kolhouse, J. F., Binder, M. J., Podell, E. R., Utley, C. S., Abrams, R. S. \& Allen, R. H. (1981). Journal of Clinical Investigation 67, 1270-1283.

Metz, J., Kelly, A., Swett, V. C., Waxman, S. \& Herbert, V. (1968). British Journal of Haematology 14, $575-592$. Miller, M., Fernandes-Costa, F. \& Metz, J. (1980). British Journal of Nutrition 44, 229-235.

Noronha, J. M. \& Silverman, M. (1962). In Vitamin $B_{12}$ and Intrinsic Factor. 2nd European Symposium, Hamburg, pp. 728-731 [M. C. Heinrich, editor]. Stuttgart: Enke Verlag.

Perry, J., Lumb, M., van der Westhuyzen, J., Fernandes-Costa, F., Metz, J. \& Chanarin, I. (1979). In Chemistry and Biology of Pteridines, pp. 315-320. [J. L. Kisluik and G. M. Brown, editors]. Amsterdam: Elsevier-North Holland.

Poston, J. M. \& Stadtman, T. C. (1975). In Cobalamin, 1st ed., pp. 141-214 [B. M. Babior, editor]. New York: John Wiley.

Scott, J. M. \& Weir, D. G. (1976). Seminars in Haematology 5, 547-568.

Taylor, R. T. \& Weissbach, H. (1971). Methods in Enzymology 18, 379-380.

van der Westhuyzen, J., Fernandes-Costa, F., Metz, J., Drivas, G. \& Herbert, V. (1982). Proceedings of the Society for Experimental Biology and Medicine 171, 88-91.

van Tonder, S. V., Metz, J. \& Green, R. (1975). British Journal of Nutrition 34, 397-410. 